Plant Tissue Cult. \& Biotech. 23(1): 127-132, 2013 (June)

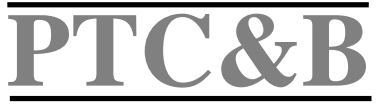

\title{
Propagation of Oroxylum indicum (L.) Vent, a Vulnerable Medicinal Tree through Organogenesis
}

\author{
Yogesh T. Jasrai ${ }^{*}$, Kalpana N. Thaker ${ }^{1}$ and Vilas R. Parmar \\ Department of Botany, University School of Sciences, Gujarat University, \\ Ahmedabad-380009, India
}

Key words: Organogenesis, Leaf explant, Vulnerable, Oroxylum indicum

An efficient protocol was developed for callus organogenesis of Oroxylum indicum (L.) Vent from leaf explant. Callus induction was achieved on MS supplemented with various concentrations of IBA and 2,4-D. Maximum number of shoot bud formation was observed on medium containing $6.78 \mu \mathrm{M}$ 2,4-D. Maximum shoot elongation growth was observed on medium supplemented with $8.88 \mu \mathrm{M}$ BA. In vitro shoots were treated at different concentrations of IBA, IAA and NAA on half strength of MS. The maximum number of roots formed on medium containing $2.22 \mu \mathrm{M}$ BA and $0.49 \mu \mathrm{M}$ IBA. The plantlets so generated were processed through hardening procedure for acclimation and transfer to the field.

Oroxylum indicum (L.) Vent belonging to Bignoniaceae is a traditional herbal medicine in many Asian countries as a cure of various diseases. Oroxylum indicum vernacularly known as 'Shyonaka' or 'Sonpatha' is a small to medium size deciduous tree with large, flat, sword shape capsular fruits of many flat and papery seeds with broad silver wings (Gokhale and Bansal 2006). Every part of this tree possesses medicinal value (Ali et al. 1998). This plant is also one of the important ingredients in most commonly used ayurvedic formulation such as Dusamula, Brahmi, Rasayana, Amratarista, Dantyarista, Dhanwantara, Ghrita, Narayana Taila etc. (Gohil et al. 2008). The root bark is used in fever, bronchitis, intestinal worms, leuoderma, asthma, inflammation and troubles etc. The fruit and seeds are used as expectorant, purgative and bitter tonic (mainly chrysin, baicalein) and certain glucosides of the flavonoids (baicalin) (Yuan et al. 2008). Baicalein is reported to possess an anti-inflammatory, anti-ulcer, anti-oxidant, hepatoprotective and immunomodulatory activity (Uddin et al. 2003). While chrysin and baicalein both are reported to have anti-bacterial, anti-fungal, and anti-viral activity, chrysin is also used as breast cancer drugs (Zaveri et al. 2008). Baicalin has been shown to reduce the total cholesterol level and have detoxification and chemo-protective effects (Yuan et al. 2008).

\footnotetext{
*Author for correspondence: <yjasrai@yahoo.com>. ${ }^{1}$ GNFC, Bharuch-392015, Gujarat, India.
} 
The estimated demand of Oroxylum indicum in Southern India is $500 \mathrm{~kg}$ per annum (Jayaram and Prasad 2008). The existence of O. indicum in natural population is highly threatened and has been categorized as vulnerable by the government of India (Ravikumar and Ved 2000). It is naturally propagated by seeds. However, the seed setting is poor and seed viability is low (Tiwari et al. 2007). Destructive and non-sustainable collection methods coupled with low regeneration and habitat destruction have posed serious threat to the survival and availability of this highly useful tree (Yasodha et al. 2004). However, largescale production is a pre-requisite to meet the pharmaceutical needs and also for the effective conservation of this valuable medicinal plant. Tissue culture techniques can be applied to generate clonal propagules and conservation efforts especially for those species in which either the underground parts or the whole plant is used in drug preparation.

Leaves of Oroxylum indicum were collected from 15 days old seedlings grown in the botanical garden of The Maharaja Sayajirao University of Baroda, Vadodara. Leaves were washed thoroughly under running tap water and then with distilled water (DW). All subsequent operations were carried out in a laminar air flow cabinet. The leaves were treated with $\mathrm{HgCl}_{2}(0.1 \%, \mathrm{w} / \mathrm{v})$ and rinsed with sterilized DW. Leaf discs $\left(1 \times 1 \mathrm{~cm}^{2}\right)$ with midrib were isolated and inoculated on MS containing 3\% sucrose, $0.8 \%$ agar and supplemented with different growth regulators. Different combinations of IBA and 2,4-D were examined for induction of callus. The leaf explants were placed with their abaxial side facing to the medium in the Erlenmeyer flasks $(150 \mathrm{ml})$. Each flask was inoculated with 3 - 4 explants and incubated in the culture room at $25 \pm 1^{\circ} \mathrm{C}$ for $16 \mathrm{hrs}$ photoperiod.

After 12 - 15 days of inoculation callus formed. It took another 12 - 15 days for shoot bud formation. The shoot buds formed on callus were transferred to the medium containing various levels of BA (Table 1) for elongation of shoot buds.

For the induction of roots, in vitro raised shoots (5-6 cm length) were transferred to half strength of MS supplemented with IBA and IAA. The plantlets were subjected to acclimation. The plantlets were removed carefully, washed thoroughly with distilled water to remove agar, dipped in dilute solution of fungicide (Bavistin, 0.1\%; w/v) and were transferred to plastic net-pots $(3.2 \mathrm{~cm}$ diam) containing perlite and soil $(1: 3)$. The plantlets were irrigated with one fourth strength MS without organic supplements. Later they were transplanted to earthen pots followed by transfer to the field.

The leaf explant (Fig. 1A) on MS supplemented with various combinations of IBA and 2,4-D showed swelling, enlargement and curling of the leaves. It took 12 - 15 days for callus formation (Fig. 1B). Further incubation for 12 - 15 days 
demonstrated shoot bud formation from callus (Fig. 1C). Almost all explants showed callus formation on the medium containing $6.78 \mu \mathrm{M}$ 2,4-D (Table 1). Among different levels of IBA $7.38 \mu \mathrm{M}$ was the optimum level found to induce callus from maximum explants. At the maximum level of 2,4-D or IBA callus induction was inhibited.

Table 1. Callus induction and shoot bud formation from seedling of Oroxylum indicum.

\begin{tabular}{|c|c|c|c|c|c|}
\hline \multicolumn{2}{|c|}{ Auxin $(\mu \mathrm{M})$} & \multirow{2}{*}{$\begin{array}{c}\text { Frequency } \\
\text { of callus* } \\
\text { (Mean } \pm \text { SE) }\end{array}$} & \multirow{2}{*}{$\begin{array}{l}\text { Nature } \\
\text { of callus* }\end{array}$} & \multirow{2}{*}{$\begin{array}{l}\text { Type of } \\
\text { callus* }\end{array}$} & \multirow{2}{*}{$\begin{array}{l}\text { No. of shoot } \\
\text { buds }^{*} \\
(\text { Mean } \pm \text { SE) }\end{array}$} \\
\hline IBA & $2,4-\mathrm{D}$ & & & & \\
\hline 0.00 & 0.00 & - & - & - & - \\
\hline 1.47 & 0.00 & - & - & & - \\
\hline 2.46 & 0.00 & $23.52 \pm 0.24$ & Light green & Nodular & $13.12 \pm 0.24$ \\
\hline 4.92 & 0.00 & $50.08 \pm 0.06$ & $"$ & $"$ & $24.66 \pm 0.21$ \\
\hline 7.38 & 0.00 & $78.92 \pm 0.11$ & White & $"$ & $33.21 \pm 0.25$ \\
\hline 12.31 & 0.00 & - & - & - & - \\
\hline 0.00 & 1.35 & $63.30 \pm 0.08$ & Light yellow & Friable & $30.80 \pm 0.21$ \\
\hline 0.00 & 2.26 & $61.44 \pm 0.20$ & Yellow & $"$ & $24.32 \pm 0.50$ \\
\hline 0.00 & 6.78 & $100.00 \pm 0.0$ & $"$ & $"$ & $56.66 \pm 0.31$ \\
\hline 0.00 & 10.85 & $78.40 \pm 0.14$ & $"$ & $"$ & $44.98 \pm 0.33$ \\
\hline 0.00 & 14.02 & $17.74 \pm 0.40$ & Dark yellow & $"$ & $20.96 \pm 0.63$ \\
\hline
\end{tabular}

*Indicates no response.

Table 2. Effect of different levels of BA on elongation of shoot buds from callus.

\begin{tabular}{lccrc}
\hline \multirow{2}{*}{$\begin{array}{l}\text { BA } \\
(\mu \mathrm{M})\end{array}$} & No. of shoots & Shoot length $(\mathrm{cm})$ & No. of nodes & No. of leaves \\
\cline { 2 - 5 } & \multicolumn{4}{c}{ Mean \pm SE } \\
\hline 2.22 & $31.86 \pm 0.35$ & $4.14 \pm 0.09$ & $2.28 \pm 0.13$ & $2.40 \pm 0.24$ \\
4.44 & $40.02 \pm 0.34$ & $4.92 \pm 0.03$ & $4.12 \pm 0.09$ & $6.00 \pm 0.34$ \\
8,88 & $54.04 \pm 0.27$ & $5.66 \pm 0.06$ & $4.42 \pm 0.20$ & $7.40 \pm 0.04$ \\
13.33 & $12.18 \pm 0.10$ & $3.72 \pm 0.18$ & $2.32 \pm 0.15$ & $3.00 \pm 0.31$ \\
17.18 & $8.48 \pm 0.23$ & $2.68 \pm 0.11$ & $2.38 \pm 0.17$ & $2.80 \pm 0.37$ \\
\hline
\end{tabular}

The callus induced on 2,4-D supplemented medium was yellow-friable and formed good number of shoot buds. In contrast, IBA induced calli was green nodular with lesser number of shoot buds.

Maximum number of shoot buds were observed on medium containing 6.78 $\mu \mathrm{M}$ 2,4-D (Fig. 1C). However, the shoot buds did not show further growth on the same medium. For elongation growth of shoot buds, when BA alone demonstrated, gave good response (Table 2). Maximum of 54 micro-shoots were obtained with $5.66 \mathrm{~cm}$ shoot length, 4 - 5 nodes and 6 - 8 leaves on the medium containing $8.88 \mu \mathrm{M}$ BA (Fig. 1D). Reduced or increased concentration of BA 
caused declining response. The decline was more pronounced when cytokinin levels were enhanced (Table 2). This indicates the role of cytokinin as critical in shoot organogenesis. Similarly, BA at lower level $(0.44 \mu \mathrm{M})$ promoted higher percentage of shoot elongation in mangosteen (Chato and Lim 1999). The good combination for shoot elongation was $8.88 \mu \mathrm{M}$ BA with $2.62 \mu \mathrm{M}$ NAA for Milingtonia hortensis (Deshpande et al. 1999).
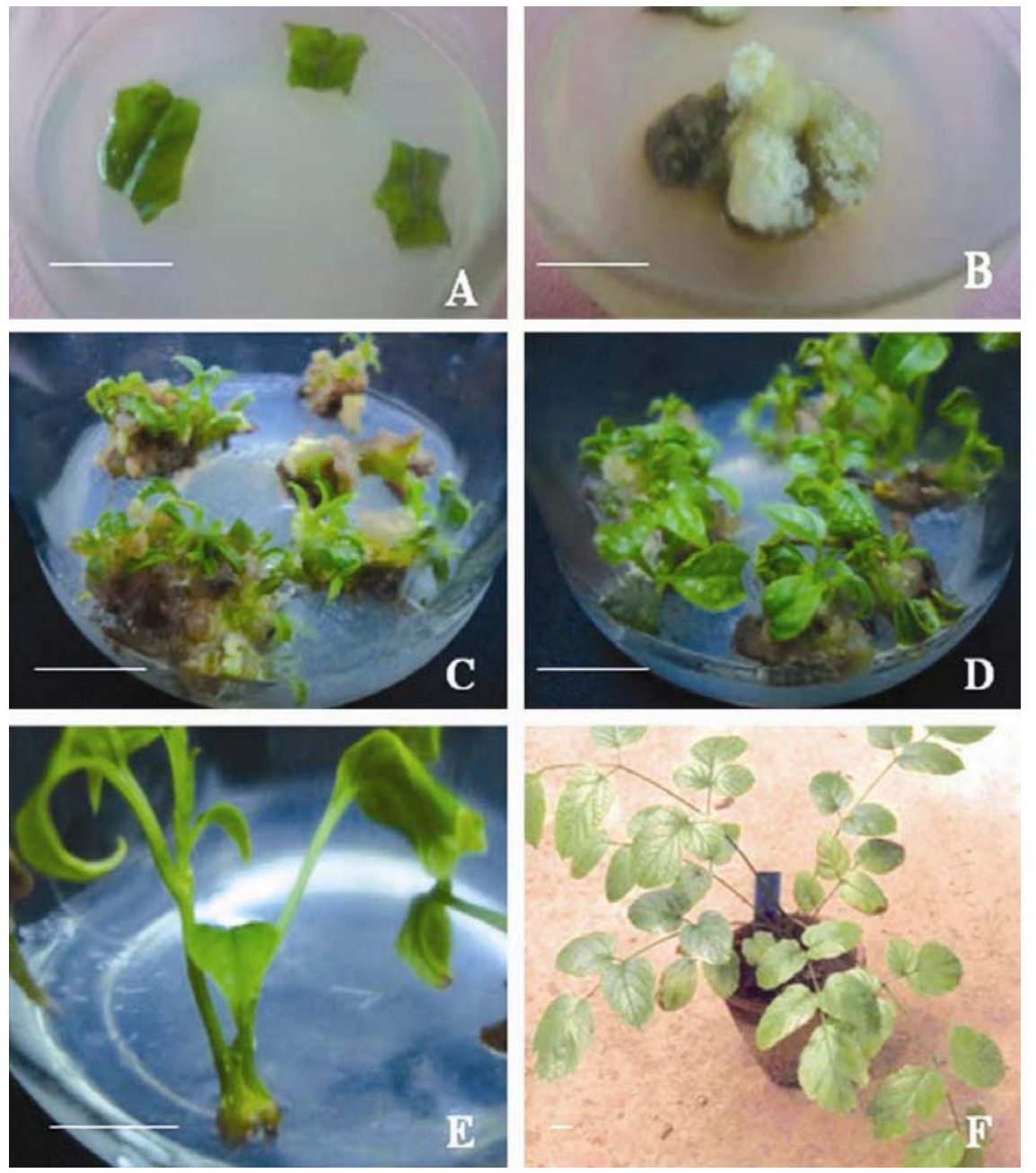

Fig. 1. Organogenesis from leaf explants of Oroxylum indicum. (A) explants, (B) friable callus on MS containing 2,4-D $(6.78 \mu \mathrm{M})$, (C) shoot bud formation, (D) further growth of shoot buds, (E) elongation growth, (F) developed plant in earthen pot. Bar in each photograph is equal to $1 \mathrm{~cm}$. 
Table 3. Root induction and growth in Oroxylum indicum with BA $(2.22 \mu \mathrm{M})$ and various auxins on agar based and liquid medium.

\begin{tabular}{|c|c|c|c|c|c|c|}
\hline \multicolumn{3}{|c|}{$\begin{array}{l}\text { Growth regulators } \\
\qquad(\mu \mathrm{M})\end{array}$} & \multicolumn{2}{|c|}{$\begin{array}{c}\text { Number of roots } \\
\text { Mean } \pm \mathrm{SE}^{*}\end{array}$} & \multicolumn{2}{|c|}{$\begin{array}{c}\text { Root length }(\mathrm{cm}) \\
\text { Mean } \pm \mathrm{SE}^{*}\end{array}$} \\
\hline IBA & NAA & IAA & Solid & Liquid & Solid & Liquid \\
\hline 0.00 & 0.00 & 0.00 & - & - & - & - \\
\hline 0.49 & 0.00 & 0.00 & $1.13 \pm 0.19$ & $1.38 \pm 0.06$ & $1.34 \pm 0.17$ & $2.54 \pm 0.10$ \\
\hline 1.47 & 0.00 & 0.00 & - & - & - & - \\
\hline 0.00 & 0.53 & 0.00 & $1.28 \pm 0.89$ & $1.24 \pm 0.10$ & $0.20 \pm 0.08$ & $0.36 \pm 0.16$ \\
\hline 0.00 & 4.30 & 0.00 & $1.05 \pm 0.04$ & $0.89 \pm 0.09$ & $0.25 \pm 0.18$ & $0.13 \pm 0.42$ \\
\hline 0.00 & 0.00 & 0.57 & - & - & - & - \\
\hline 0.00 & 0.00 & 2.85 & - & - & - & - \\
\hline 0.00 & 0.00 & 4.57 & - & - & - & - \\
\hline
\end{tabular}

*indicates no response.

For induction of roots, in vitro raised shoots $(5-6 \mathrm{~cm}$ length) were treated with range of IBA, IAA and NAA at various concentrations on half strength of MS. Poor root induction was observed on micro-shoots of Oroxylum (Table 3). The roots were extremely thin, spongy and fragile. The maximum number of roots formed were 1.38 with $2.22 \mu \mathrm{M}$ BA and $0.49 \mu \mathrm{M}$ IBA. The growth of induced roots was quite slow. The attained a length of only $2.54 \mathrm{~cm}$ after 21 days of induction. The in vitro raised plants were acclimatized well in the greenhouse conditions (Fig. 1F). The plantlets transferred to the field showed homogeneity in growth and general morphological features suggesting absence of any variations.

\section{References}

Ali RM, Houghton PJ and Hoult JRS (1998) Antimicrobial and anti-inflammatory activities of extracts and constituents of Oroxylum indicum (L.) Vent. Phytomed. 5: 375-381.

Chato ST and Lim M (1999) Plant regeneration of mangosteen via nodular callus formation. Plant Cell Tiss. Org. Cult. 59: 89-93.

Deshpande SR, Josekutty PC and Senan GP (1999) Indirect organogenesis in Millingtonia hortensis Linn from nodal callus. Phyton. 65: 197-200.

Gohil P, Zaveri M and Jain S (2008) Immunomodulatory activity of n-Butanol extract of Oroxylum indicum. Pharmaceutical Biol. 12: 914-919.

Gokhale M and Bansal YK (2006) An avowal of importance of endangered tree Oroxylum indicum (L) Vent. Natural Product Radiance 5: 112-114. 
Jayaram K and Prasad MNV (2008) Genetic diversity in Oroxylum indicum (L.) Vent (Bignoniaceae), a vulnerable medicinal plant by random amplified polymorphic DNA marker. Afri. J. Biotech. 7: 254-262.

Uddin K, Sayeed A, Islam A, Rahman AA, Ali A, Khan GRMAM and Md Sadik G (2003) Purification, characterization and cytotoxic activity of two flavonoids from Oroxylum indicum Vent (Bignoniaceae). Asian J. Plant Sci. 2: 515-518.

Ravikumar K and Ved DK (2000) One hundred red listed medicinal plants of conservation concern in Southern India. Foundation for Revitalization of Local Health Traditions. Bangalore, India.

Tiwari S, Singh K and Shah P (2007) In vitro propagation of Oroxylum indicum - An endangered medicinal tree. Biotech. 6: 299-301.

Yasodha R, Ghosh M, Santan B and Gurumurthi K (2004) Importance of biotechnological research in tree species of Dashmula. Indian Forest. 130: 79-88.

Yuan Y, Wenli H, Minhai T, Houding L, Li-Juan C, Hugh GY and Sutherland IA (2008) Separation of flavonoids from the leaves of Oroxylum indicum by HSCCC. Chromatographia 68: 885-892.

Zaveri M, Khandhar A and Jain S (2008) Quantification of baicalein, chrysin, biochanin-A and ellagic acid in root bark of Oroxylum indicum by RP-HPLC with UV detection. Eurasian J. Anal Chem. 3: 245-257. 